\title{
BLENDED LEARNING IN PRACTICE: THE IMPACT OF AN ECONOMIC SIMULATION GAME ON PERCEIVED LEARNING
}

Márta Aranyossy - Eszter Kulcsár ${ }^{1}$

\begin{abstract}
The goal of our analysis, in connection with the use of simulations in higher education, is to examine whether this method is suitable for making knowledge transfer more enjoyable and efficient. With the help of a questionnaire, we measured the perceived learning retention of students, as well as how much they enjoyed courses and challenging tasks. Besides descriptive statistical methods for the analysis of the data, we also applied PLS path modelling. Our results revealed that a challenging, exciting and enjoyable simulation game has a positive impact on perceived learning. At the same time, challenging tasks or merely exciting exercises do not alone achieve a significant effect if the enjoyment factor is missing as a feature of the simulation game.
\end{abstract}

JEL code: I 21

Keywords: blended learning, digital education, practical learning, game-based learning, simulation

\section{INTRODUCTION}

Empirical investigations show that traditional learning methods such as lectures, reading, audio-visual tools and even demonstrations attain a maximum 30\% learning retention (see Figure 1, Motorola University, 1996). By contrast, interactive methods such as discussion groups, practice by doing and teaching others may achieve as much as $90 \%$ retention. Changes occurring in the learning environment in recent decades have also led to a shift towards more practically oriented methods. Beginning from the 1960 s and 1970s, the evolution of information and telecommunications technologies has created new opportunities, mak-

1 Márta Aranyossy, Associate professor at Corvinus University of Budapest. E-mail: marta. aranyossy@uni-corvinus.hu.

Eszter Kulcsár, Senior HR coordinator at European Central Bank. E-mail: kulcsareszter9o@ gmail.com. 
ing accessible an increasing number of atypical forms of learning. Within these, distance education and e-learning have become defining trends (Merkovity and Nemeslaki, 2014).

\section{Figure 1}

The learning pyramid, teaching methods and retention

METHOD
Lecture
Reading
Audio-Visual
Demonstration
Discussion Group
Practice by Doing
Teach Others

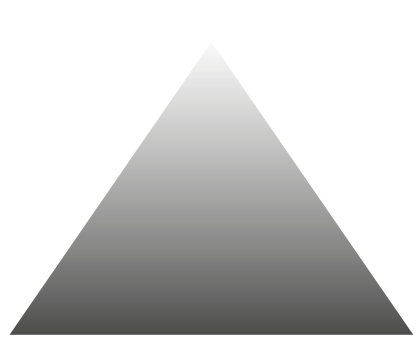

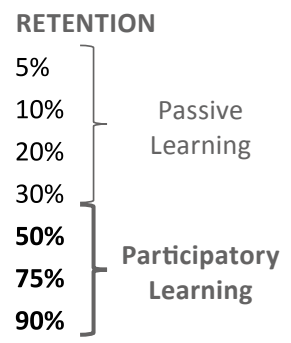

Source: compiled by authors, based on Motorola University, 1996

Our study begins by discussing the concepts of blended learning, gamification and simulation, summarising the results of a number of related empirical research studies. We then go on to present the question related to the efficiency of simulations that guides our research, as well as the modelling, data collection and analytical methods we have applied in our endeavours to explore the question of our research. Finally, we analyse the results of our research in detail and the conclusions that can be drawn from it, before closing our study by outlining the limitations of the research and the potential broader applications in future.

\section{BLENDED LEARNING, GAMIFICATION, SIMULATION - BASIC CONCEPTS AND AN OVERVIEW OF THE LITERATURE}

\subsection{Blended learning}

In their study, Gergö Docsa and Péter Szlávik (2015) identified three main types in order to differentiate among various educational methods, these being: (1) traditional "face-to-face" education, carried out in person and typically in classrooms; (2) "distributed" or distance education; and (3) "blended learning," which combines learning methods. Traditional education, in which teacher and students are present at the same location and time, is currently the most widespread form worldwide. Distance education, on the other hand, does not require partici- 
pants to be in one place at one time, with knowledge being indirectly transferred by means of teaching materials. The third type, blended learning, is a combination of the first two, blending elements applied in both traditional and distance education.

The authors of "The Handbook of Blended Learning" (Bonk and Graham, 2006) define blended learning systems as those which combine face-to-face and computer-mediated instruction. Phrased somewhat differently in the definitions of Greer, Rowland and Smith (2014), or Behjat, Yamini and Bagheri (2012), blended learning signifies an educational environment where students carry out their tasks partly on computers, and partly in a traditional classroom environment together with their teachers and fellow students. All this is facilitated largely by means of IT solutions, with distance education frequently taking the form of elearning (see Forgó, 2009). Figure 2 illustrates a system of criteria in which fresh solutions can be worked out experimentally along set prevailing dimensions. Along these dimensions, blended learning appears somewhere between the two extremes, approaching one or other of the first two methods depending on the specific characteristics of its application.

\section{Figure 2}

\section{Four dimensions of interaction of traditional and distance learning}

\begin{tabular}{|c|c|c|c|}
\hline \multirow{2}{*}{ SPACE } & Live & Mixed & Virtual \\
\hline & \multicolumn{2}{|l|}{ (Physical, face-to-face) } & (Distributed) \\
\hline TIME & \multicolumn{2}{|l|}{ Synchronos } & Asynchronos \\
\hline \multirow{2}{*}{ FIDELITY } & Rich & Medium & Low \\
\hline & (Impacts several senses) & (e.g. text and audio) & (e.g. text only) \\
\hline \multirow{2}{*}{ HUMAN PRESENCE } & High & & Low \\
\hline & (no machine) & & (With machine) \\
\hline
\end{tabular}

Source: based on Bonk and Graham, 2006

The question may arise as to why there exists any desire at all to mix already existing, separately functioning methods. According to Osguthorpe and Graham (2003), the most important motivating drivers are pedagogical advancement, and increased accessibility, flexibility and cost efficiency, as all-embracing categories. Expectations for the future, meanwhile, reveal that blended learning will prove to be a generally accepted concept in education, and will become increasingly popular both in higher education (see Garrison and Kanuka, 2004) and in the field of corporate education. 


\subsection{Changing student demands}

The pace of digital advancement accelerated from the second half of the 2oth century, as the appearance of the internet led to the evolution of a newer, faster world. Many regard this as a third industrial revolution, impacting every sphere of life, education included. These changes altered not only the tools of education, but the demands of students. At the start of the new millennium, Marc Prensky (2001) investigated the changing demands of American students, at a time when the students going to school were those who had been born and integrated into society in the context of the digital world. Members of this generation grew up surrounded by computers, video games, mobile telephones, and other digital devices. They developed an altered way of thinking as a consequence, with a brain structure adapted in response to different experiences of childhood. Members of this new generation have become accustomed to receiving information quickly, favouring a multifunctional way of thinking and seeing things. They prefer to access information randomly and to think in groups, favouring rapid results and frequent rewards, and they would rather play than study.

With something of a delay, digitalisation and its effects on the education system and methods also became a topical issue in Hungary (see for example Csapó, 2002). In their article, Docsa and Szlávik (2015) emphasised that new digital tools enter the market with increasing rapidity these days in the wake of technological advances. As a consequence, the time available to educational institutions to adapt these new tools and convert them into a competitive advantage has diminished to such an extent that the application of new technologies no longer represents an advantage, but rather a fundamental requirement amid market competition. Given that there is also competition for students among universities, the latter are obliged to utilise new technologies to win and retain students. Docsa and Szlávik also highlight that the demands of students of the new generation have changed, so that interactive tools must be deployed to gain their attention. Among the methodical approaches that offer solutions, the authors emphasise teamwork, computer laboratories, games and simulations.

All these tools help develop students' commitment to their studies, while practical methods increase the efficient conversion of taught material into knowledge. Digital solutions aid students in accessing and understanding, and in many cases mastering and revising learning materials. The blended learning approach mostly expects more of students; that they should take the learning process in hand, assume responsibility for it, and motivate themselves (Krishnan, 2016). In return, it naturally also offers greater autonomy and control to the students during the learning process (Tao, Cheng and Sun, 2009). 
These new opportunities also represent an advantage for educators, albeit potentially making it more difficult for them to manage lessons. Lalima and Dangwal (2017), for example, emphasise that a basic condition for the successful application of blended learning - besides the availability of the technology and continuous internet access - is a well-trained educator with a scientific attitude who is open to change. Putting the theory into practice can develop into a longer process, since it requires educators to prepare for a number of tasks in a variety of ways. The effort is worth the trouble, however, since the efficiency of blended learning methods developed in this way greatly surpasses that of traditional education (Docsa and Szlávik, 2015).

\subsection{Simulation and gamification}

Aligning with all these trends, gamification and simulation have also become more widely applied approaches to learning and teaching. In this context, the term "game" denotes a game-like contest circumscribed by rules and aimed at achieving defined goals (Deterding, Dixon, Khaled and Nacke, 2011), within an artificial environment - but with genuine goals in mind in the process of gamification.

The spread of simulations is a divergent but often interlinked trend. Simulations are simplified mappings of reality which take a systems approach to modelling certain variables and dynamic relationships between them (Sauvé, Renaud, Kaufman and Marquis, 2007). The application of simulations in education fits in well with the experiential learning approach espoused by Carl Rogers (1969) and later David A. Kolb (1984).

In the specialised literature in recent years, a growing number of authors have emphasised the educational advantages of simulation games (Geithner and Menzel, 2016; Ranchhod, Gurău, Loukis and Trivedi, 2014), highlighting the positive motivational impact and the effects of student-centred skills development. These applications combine the entertainment-based benefits of gamification with the practicality of simulations, thus breaking the monotony of traditional classroom teaching (Matute and Melero, 2016). The research of Matute and Malero (2016) relating to university simulation games demonstrates that students find them entertaining, associating them with positive emotional states such as enthusiasm or the experience of flow - while all the time also finding them useful. In their research, Ranchhod et al. (2014) examined four valuable impacts of simulation games (experience generation, conceptual understanding, skills development, and affective evaluation), reaching the conclusion that experience generation has a strong impact on conceptual understanding, and that both impact skills development. 


\section{RESEARCH QUESTION, MODEL AND METHODOLOGY}

The fundamental question is whether students should accept existing methods, or if educators should adapt to students' changed demands. Our belief is that the goal of education is the transfer of knowledge, and that good educators strive to achieve this as successfully as possible. For this they need to know how to motivate their students, and to select the appropriate means of education on this basis. Generations $\mathrm{X}, \mathrm{Y}$ and $\mathrm{Z}$ are all children of the digital world, for whom a world without digital devices is unknown. For this reason, studies of the past decade have particularly emphasised the advantages of blended learning applying game-based solutions. Game-based learning can be more entertaining and pleasurable, as students acquire practical and experiential knowledge with more efficient knowledge transfer.

In our research, we examined whether the positive effects described in the specialised literature can be demonstrated empirically, using a Hungarian sample. The focus of our inquiries was on economic simulation games in higher education undertaken within a blended learning framework. Our question therefore was: Does an online simulation game have a positive impact on the perceived learning of university students of economics?

To explore the question of our research, we took the game-based learning study model of Hamari et al. (2016) as a basis. The authors' hypothesis here was that the experience of flow (comprised of challenge and skill), as well as engagement and immersion in the game, positively impact perceived learning (see Figure 3). Their research involved the participation of 134 high school and 40 undergraduate mechanical engineering students in the United States, who filled in a survey comprising 19 questions relating to a gamified solution used during their studies. The results revealed that skill, challenge and engagement all have a positive effect on perceived learning. The key finding of the research confirmed that use of the studied games effectively complemented education, enhancing students' engagement, which was increased still further by challenging tasks and the promotion of students' skills.

\section{Figure 3}

Hamari et al. (2016) research model

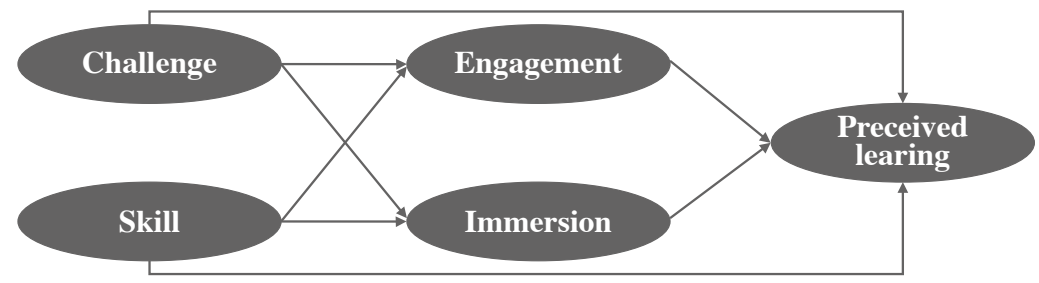

Source: Hamari et al. (2016:174) 
We used the research model and validated questionnaire of Hamari et al. (2016) when planning our research. When collating data through the questionnaire, we posed questions to participating students with responses measured along a similar, closed 10-point Likert scale. While a response with a value of 1 meant that the respondent entirely disagreed with the stated proposition, a value of 10 indicated total agreement. The 10-point scale ensured that respondents were in all cases obliged to adopt a position in some degree of agreement or disagreement with the proposition. The questionnaire comprised a total of 19 questions, of which two questions were reverse-coded. ${ }^{2}$

Software by SimTeam Training Kft., a gamified educational tool (serious game) going by the same name, served as the subject of our empirical study. SimTeam is an online business simulation software tool that models a project-based corporate environment. Participants in teams of four manage virtual companies operating on the same market, competing with each other for client projects and employees capable of carrying them out. Team members fulfil four different roles (Team Leader, Sales Manager, HR Manager, and Finance Manager), thus forming the model company's senior management. The simulation contains both soft and hard rules, and by observing or ignoring these, the team controlling the model company is able to influence the success of projects and the profitability of the company.

SimTeam's simulation is used by its partners in order to attain more efficient knowledge transfer and to provide experience-based learning to participants in its management training programmes. The company also has links with universities and university educators, so that the SimTeam simulation is also used at Corvinus University of Budapest and the Budapest Business School. During the research we contacted four university tutors who have used the SimTeam simulation software in teaching their courses. ${ }^{3}$ In these courses, students studied applied business economics, personnel controlling, and basics of entrepreneurship. Following lectures on theory, the teachers used the simulation in seminars to offer students the opportunity to experience the already learned theoretical background in practice. With the consent and cooperation of the tutors, we sent the questionnaire to every course participant at the end of the 2015/16 academic year. A total of 111 students completed the survey in the course of the research, amounting to $69 \%$ of the full 162 -strong population (see Table 1).

2 The two reverse-coded questions in the questionnaire (questions 10 and 11) were recoded after the collection of data. The original value of 1 corresponds to a value of 10 , the value of 2 to 9 , and so on.

3 Here we would like to express our thanks to the tutors who made the research possible, particularly Dr. György Boda, Dr. Zsolt Matyusz, Dr. Miklós Stocker, and Dr. Attila Petheö. 
Table 1

Composition of university groups

and overall sample participating in research

\begin{tabular}{lcccccc}
\hline Groups: & A & B & C & D & E & Total \\
\hline $\begin{array}{l}\text { Number of } \\
\text { students taking } \\
\text { part in course }\end{array}$ & 29 & 62 & 29 & 20 & 22 & $\mathbf{1 6 2}$ \\
$\begin{array}{l}\text { Number } \\
\text { completing } \\
\text { questionnaire }\end{array}$ & 15 & 37 & 29 & 12 & 18 & $\mathbf{1 1 1}$ \\
$\begin{array}{l}\text { Ratio of } \\
\text { completions }\end{array}$ & $51.74 \%$ & $59.68 \%$ & $100 \%$ & $60 \%$ & $81.82 \%$ & $\mathbf{6 8 . 5 2 \%}$ \\
$\begin{array}{l}\text { Language of } \\
\text { completion }\end{array}$ & Hungarian Hungarian Hungarian & English & Hungarian & \\
$\begin{array}{l}\text { Method of } \\
\text { completion }\end{array}$ & online & online & paper & online & paper & \\
\hline
\end{tabular}

Source: own calculations

Besides descriptive statistical methods, we also applied PLS (partial least squares) modelling in our analysis. PLS is an SEM (structural equation modelling) technique that simultaneously enables estimation of the structural model (the relationship between latent variables) and the measurement model (generating the latent variables from the observable variables), in an iterative fashion, maximising variance. Compared to other SEM techniques, PLS eliminates - for example - the problem of factor indeterminacy, while raising minimal demands on measurement scales, sample size and distribution (Chin, 1998:295). This choice of methodology also permitted us to compare our Hungarian research results with the results of the research by Hamari et al. (2016), as well as to build an independent model.

\section{RESULTS}

\subsection{Descriptive statistics}

Table 2 illustrates the general characteristics of responses given to the questions in the survey. In the table we have highlighted mean and median averages of 5 or lower, modes of 1, 2 or 10, instances greater than 5 in the case of variance, the smallest spreads and the greatest minimum values, while indicating the direction of skewness. It emerges from the table that 111 valid responses were available for every question, meaning that everyone who completed the questionnaire answered every single question, and thus no data were missing. 


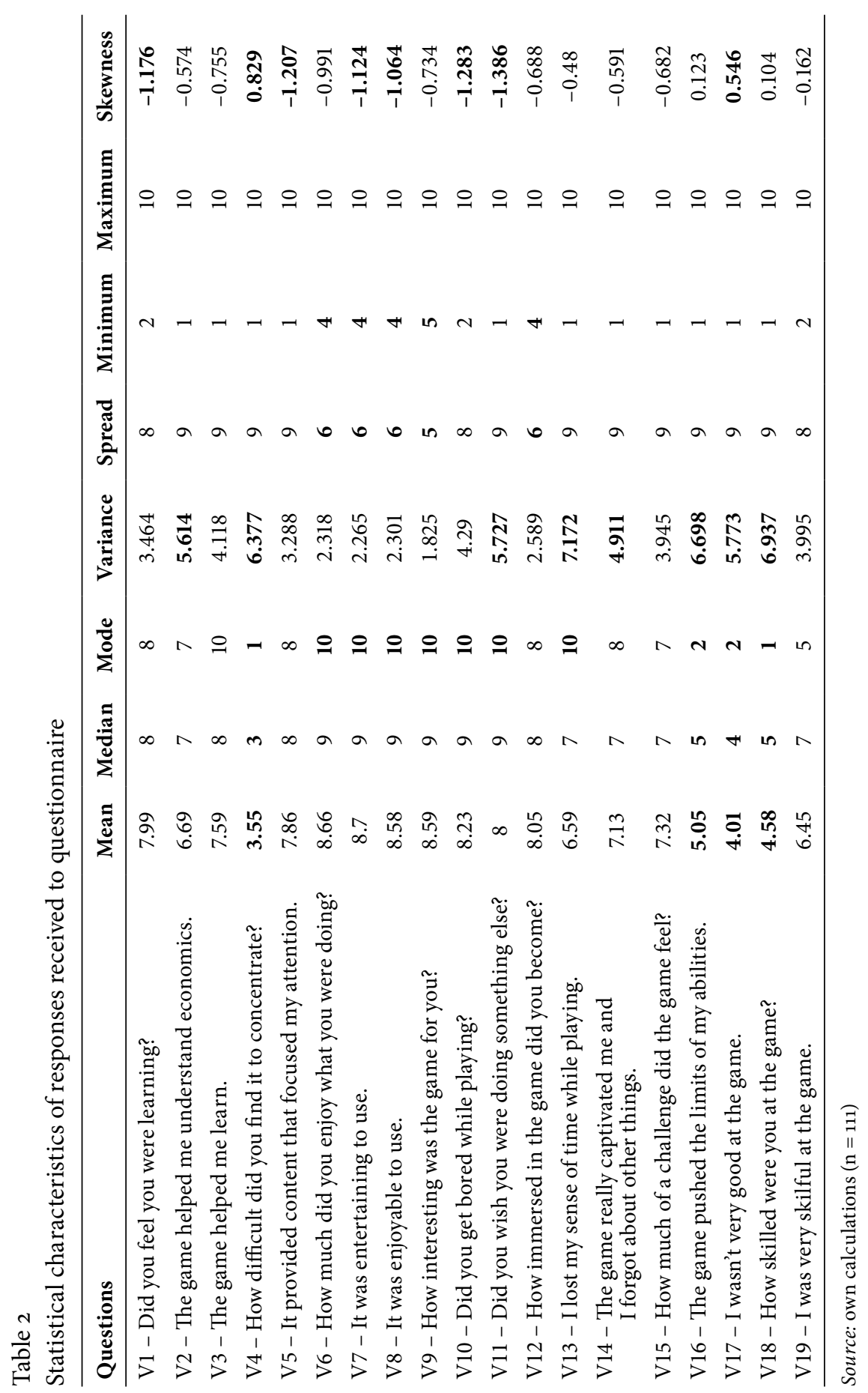


With respect to the overall responses to the questionnaire, the mean, mode and median averages move together in most cases, showing similar values. Exceptions to this are questions $4,16,17$ and 18 , where the results reveal mixed opinions among respondents concerning the given issues (difficulty in concentrating, pushing of limits, assessments of own performance and proficiency); however, the mode values reveal that the majority still disagreed with these propositions. High variance values (besides the aforementioned questions, also seen in the case of level of understanding, support, or preference for other activity) also highlight a diversity of opinions, while low spreads (in the case of questions 6-9, i.e. those relating to enjoyment) show that students adopted a relatively unanimous opinion on these questions. The skewness of the responses also reveals that most students felt they had genuinely learned something; that the game had helped focus their attention; that they had found the lesson entertaining and enjoyable; that consequently they had not become bored or wanted to do something else; that they had in fact had no difficulty concentrating; and that they did not agree they lacked skill in the game.

\subsection{Path modelling - a comparative approach}

We carried out the further analysis of our own data with the help of the SmartPLS 3 program, which was developed expressly for the application of PLS-SEM. There are various rules of thumb for the number of elements in a sample, of which we applied the 10 rule (Hair, Hult, Ringle, Christian and Sarstedt, 2017:24), which states that the minimum number of elements in a sample should be ten times the variables of the model. Our model and the size of our sample conform to this condition.

Figure 4 below shows the PLS model constructed according to the research model of Hamari et al. (2016). Besides the latent variables forming the structural model (ellipses), it shows the related indicators (rectangles V1-V19; see in detail in Table 2), the directions of relationships, and the results of the PLS modelling. Within the structural model, standardised path coefficients appear along the arrows, while the $\mathrm{R}^{2}$ values are shown within the ellipses of the latent variables. 


\section{Figure 4}

Result of path modelling based on the model of Hamari et al. (2016), testing relationships with own data

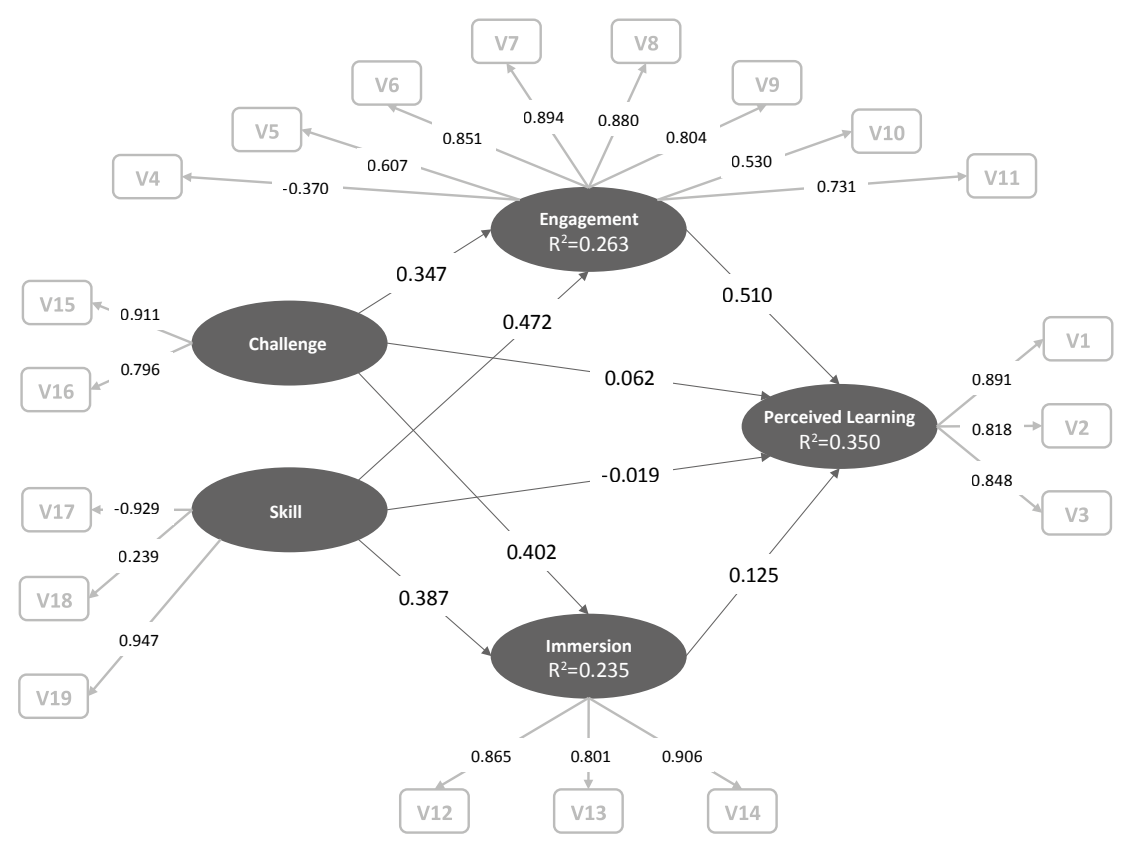

Source: own calculations

Based on tests examining the reliability and validity of the latent variables, the composition of the Skill latent variable is inadequate, while a Cronbach $\alpha$ indicator below the threshold value in the case of both Challenge and Skill indicates that the indicators attached to the latent variables are not uniformly reliable, and furthermore that five indicators in the context of factor loading performed below the generally accepted threshold value. This therefore suggests that the questions adopted from the Hamari research, translated into Hungarian, were not directly suitable - in a Hungarian context - for measuring the complex factors they predetermined, or that there was a different pattern of relationships between the questions. We should also mention - comparing the factor loading of the indicators with the survey by Hamari et al. (2016) - that in the latter case only three values attached to the variables were less than o.7. Based on the test, there was no multicollinearity within the model.

We utilised a bootstrapping procedure for examining the significance of the path coefficients, for which we applied a 5\% significance level and bilateral test. Examining the direct and indirect effects, it emerged that Engagement had the great- 
est impact on Perceived learning, followed by Challenge, Skill and Immersion; however, of these, only the first two were significant. Challenge made its effects on learning felt indirectly through both Engagement $\left(\beta=0.347^{\star}\right)$ and Immersion $\left(\beta=0.402^{\star}\right)$, with the indirect impact greater than the direct one.

By way of comparison, the results of Hamari et al. (2016) revealed that Challenge had the greatest impact on Perceived learning $(\beta=0.695)$, followed by Engagement $(\beta=0.474)$, Skill $(\beta=0.209)$ and Immersion $(\beta=0.084)$. From this comparison, and from an examination of the determinative coefficient of the latent variables $\left(\mathrm{R}^{2}\right)$, it emerged that the explanatory power of the latent variables in a repeated test of the model on a Hungarian sample was lower in every case. Cultural differences between participants in the research may also explain why Challenge played the greatest role in influencing Perceived learning in the case of students surveyed in the United States, while for Hungarians it was Engagement - although it is possible that the divergent results may be partly attributable to the inadequacies in measurement already revealed in relation to the assimilation of factor analysis.

\subsection{Results of our own PLS model}

Based on all this, following reconstruction of the Hamari survey, we used objective multivariate statistical methods to build our own model to be applied to our Hungarian sample. To configure the latent variables, we used factor analysis, and within this a principal component analysis procedure. ${ }^{4}$ We used the same database as before for the factor analysis, so that it would not be corrupted by missing data or outliers. We assumed that the number of latent variables employed earlier would not change and applied a varimax rotation. We applied the Kaiser criterion for the analysis, ending up with five variables that fulfilled the criterion of an eigenvalue of greater than one. These five factors explained $70 \%$ of the total variance, which exceeds the $60 \%$ threshold value. Our results were satisfactory with respect to both the $\mathrm{KMO}^{5}$ and Bartlett $^{6}$ tests.

4 In the case of factor analysis, there are several rules of thumb with respect to the minimum number of elements, among which we applied the $n \geq 5 p$ rule proposed by Erzsébet Kovács, where $\mathrm{n}$ is the number of observations, and $\mathrm{p}$ the number of variables (Kovács, 2011:89). On this basis, the 111 observations we collected actually exceeds the minimum requirement, i.e. $5 \times 19=95$ elements.

5 The Kaiser-Meyer-Olkin (KMO) criterion is one of the most frequently used measures to determine the degree of adequacy of the examined variables for factor analysis (CERNY and KAISER, 1977). A KMO value of over o.8 indicates a very good degree of adequacy.

6 Bartlett's test examines whether the variables are non-correlative (SNEDECOR and CocHRAN, 1989). A condition of factor analysis is that there should be correlation among the variables. 
The results are illustrated in the following two tables. Table 3 shows the adequacy of the Hungarian sample, while Table 4 compares the factors (headings) and the attached variables (question numbers) of the Hamari et al. (2016) model with the composition of the latent variables in the Hungarian model.

Table 3

Testing the adequacy of the Hungarian sample and the independence of the variables

\begin{tabular}{lcc}
\hline Kaiser-Meyer-Olkin index & & 0.822 \\
\hline \multirow{2}{*}{ Bartlett's test } & chi-square & 1182.414 \\
& df & 171 \\
& sig. & 0.000 \\
\hline
\end{tabular}

Source: own calculations

Table 4

Composition and comparison of latent variables

in the Hamari et al. (2016) and Hungarian models -

i.e. which questions (V1-V19) are contained in which factors

\begin{tabular}{|c|c|c|c|c|c|c|c|c|c|}
\hline \multicolumn{5}{|c|}{ Hamari et al. (2016) classification } & \multicolumn{5}{|c|}{ Based on factor analysis } \\
\hline 承 & 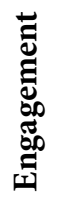 & 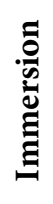 & 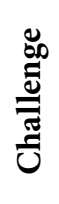 & $\frac{\bar{z}}{5}$ & & 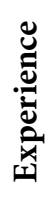 & 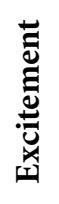 & 总 & $\underset{\sigma}{\sigma}$ \\
\hline 1 & 4 & 12 & 15 & 17 & 1 & 6 & 4 & 15 & 18 \\
\hline 2 & 5 & 13 & 16 & 18 & 2 & 7 & 10 & 16 & \\
\hline \multirow[t]{6}{*}{3} & 6 & 14 & & 19 & 3 & 8 & 11 & 17 & \\
\hline & 7 & & & & 5 & 9 & & 19 & \\
\hline & 8 & & & & & 12 & & & \\
\hline & 9 & & & & & 13 & & & \\
\hline & 10 & & & & & 14 & & & \\
\hline & 11 & & & & & & & & \\
\hline
\end{tabular}

Source: own calculations

It is apparent from Table 4 that, while our results are similar to those of the American research, a number of variables were included under different factors. Since the composition of the new factors obtained in the course of our own analysis changed, the latent variables were given new umbrella terms, these being Learn- 
ing, Experience, Excitement, Challenge and Skill. The latent variable Skill had no significant effect on any other latent variable, and given that a latent variable characterised by a sole indicator is not recommended in the case of a sample of elements numbering more than 50 (Hair et al., 2017), we decided to remove this variable from the model (along with the corresponding indicator).

In the case of the formative measurement models, a test of multicollinearity revealed that the VIF values of questions V7 and V8 exceeded the threshold value of 5. This is understandable, given that one question examines the game's enjoyment level, and the other its entertainment value. Since the factor loading value of the V8 indicator was somewhat higher, we retained this indicator while removing $\mathrm{V}_{7}$ from the model. Similarly, we also had to omit the V16 indicator from the model as it proved insignificant in this context. A further assumption with respect to Excitement was that it would have an effect not just on Learning, but also on Experience. We began testing of the model thus developed (see Figure 5) by running PLS algorithm and bootstrapping procedures.

\section{Figure 5}

\section{Results of the PLS SEM on the newly developed model}

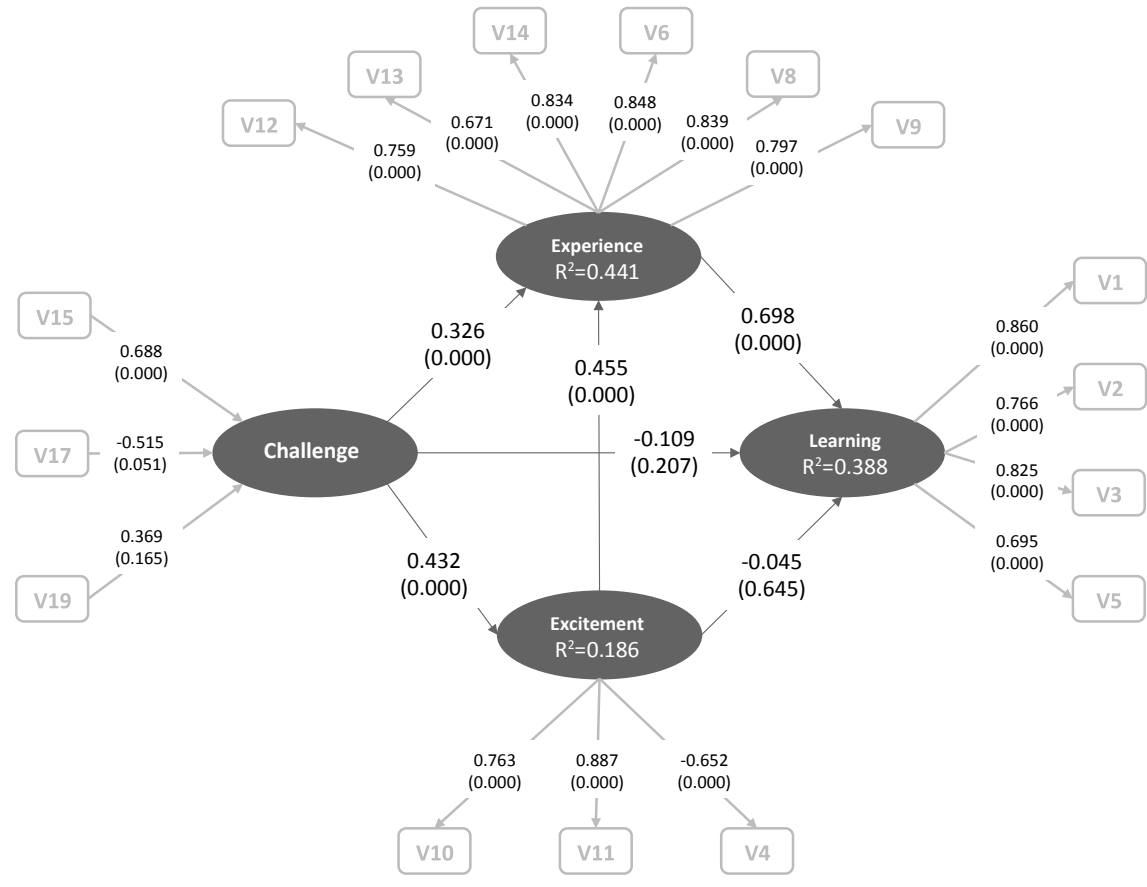

Source: own calculations 
The indicators required for evaluation of the reflective measurement model are summarised in Table 5. The Fornell-Larcker criterion is fulfilled in every case, since the AVE value of all three reflective latent variables is acceptable. In terms of the factor loading of the indicators, there is a value of below 0.7 in the case of both Learning and Experience; however, these are also very close to this acceptable value.

\section{Table 5}

Reliability and validity of latent variables and Fornell-Larcker criterion in new model

\begin{tabular}{lccccccc}
\hline & \multicolumn{2}{c}{$\begin{array}{c}\text { Reliability and validity of } \\
\text { variables }\end{array}$} & \multicolumn{4}{c}{ Fornell-Larcker criterion } \\
\hline & $\begin{array}{c}\text { Cronbach } \\
\text { a indicator }\end{array}$ & CR & AVE & Excitement Challenge & Learning Experience \\
\hline Excitement & -0.448 & 0.452 & 0.598 & 0.773 & & & \\
Challenge & & & & 0.432 & & & \\
Learning & 0.800 & 0.868 & 0.622 & 0.323 & 0.236 & 0.789 & \\
Experience & 0.887 & 0.914 & 0.639 & 0.596 & 0.522 & 0.614 & 0.800 \\
\hline
\end{tabular}

Source: own calculations

In the case of the formative measurement model there is no longer any multicollinearity, since we removed the $\mathrm{V}_{7}$ variable from the model. Finally, examining the structural model, it can be stated that there is no multicollinearity in the model, and the path coefficients are mostly significant. The effects - also illustrated in Figure 5 - are summarised in Table 6 below.

Table 6

Direct, indirect and overall effects in the new model $\left({ }^{*}: \mathrm{p}<0.05\right)$

\begin{tabular}{lccccccc}
\hline Examined effect & \multicolumn{2}{c}{ Direct effect } & \multicolumn{2}{c}{ Indirect effect } & \multicolumn{2}{c}{ Overall effect } \\
\hline & $\ldots \rightarrow$ Learning & $\boldsymbol{\beta}$ & $\mathbf{p}$ & $\boldsymbol{\beta}$ & $\mathbf{p}$ & $\boldsymbol{\beta}$ & $\mathbf{p}$ \\
\hline Excitement & -0.045 & 0.645 & $\mathbf{0 . 3 1 8}^{*}$ & 0.000 & $\mathbf{0 . 2 7 3}^{*}$ & 0.012 \\
Challenge & -0.109 & 0.207 & $\mathbf{0 . 3 4 5}^{*}$ & 0.000 & $\mathbf{0 . 2 3 6}^{*}$ & 0.014 \\
Experience & $\mathbf{0 . 6 9 8}^{*}$ & 0.000 & - & - & $\mathbf{0 . 6 9 8}^{*}$ & 0.000 \\
\hline
\end{tabular}

Source: own calculations

7 The Cronbach a indicator belonging to Excitement indicates that the indicators are not uniformly reliable, while the $\mathrm{CR}$ indicator calls attention to the shakiness of the composition. This is due to the $\mathrm{V}_{4}$ indicator, the factor loading value of which is -0.625; however, even when removing this the Cronbach $a$ indicator does not reach the threshold value, and so we retained this variable in the model. 
In the model, it is Experience that has the greatest, significant effect on Learning, followed by Excitement and Challenge. It is interesting that the direct impact of Excitement and Challenge on Learning is negative in both cases, although these values are not significant, i.e. hovering around the zero mark. This, on the other hand, means that their indirect effect is strong, as can be seen from the table. It is also interesting that Challenge has a significant effect on Excitement, but since Excitement has no significant direct effect on Learning, then every impact on Learning deriving from Challenge makes itself felt through Experience. In other words, Challenge positively influences Experience both directly and indirectly.

With regard to the explanatory power of the latent variables in the model, Experience has the highest $\mathrm{R}^{2}$ value (44.1\%), followed by Learning $(38.8 \%)$ and Excitement (18.6\%).

\section{CONCLUSIONS}

Taking part in our research were 111 students who used online business simulation software in the course of their studies in economics. Primary data analysis and control questions alike confirmed that students found classes supplemented with the simulation to be genuinely enjoyable and exciting. The majority responded that the game helped them understand the course material and aided their study, so that they genuinely felt they had learned something during their courses. Naturally this is not only attributable to the use of the simulation program alone, since it has little value in itself without the expertise of an educator. The overall observed positive experience and impacts on learning efficiency are in keeping with those experienced in both an international and domestic context (Pásztor, 2014).

The game got the students involved in an efficient manner, and producing a good performance proved a challenge for most. Overall participants did not feel they had been very skilful in playing the game; nevertheless they tended more to interpret this as a challenge. Naturally, this is also connected to the fact that they were not well-versed in the game, given that they had had no previous experience of the simulation.

During the PLS path analysis, we examined the questions relating to Challenge, Experience and Learning based on the model of Hamari et al. (2016), as well as within the PLS model accommodated to our own sample.

Incorporating the results of our own questionnaire into the Hamari model, it emerged that students viewed Engagement and Challenge as having the greatest impact on Perceived learning, while Skill and Immersion had no significant effect. This chimes with the original research carried out among American stu- 
dents, although in their case Challenge proved the strongest and Engagement placed second in the examination of impacts. Taking into account the impact whereby the mastery motivation functions well when the goal has optimal challenging power (Józsa, 200o), this demonstrated effect may be instructive both in designing simulations internationally and, for example, in employing American simulation games in Hungary, since - to take one aspect - it may be potentially worthwhile to set the nature of the challenge somewhat lower in the case of Hungarian students.

It emerged from evaluation of the results of the new Hungarian model that the effects of Challenge and Excitement on Learning were only indirectly significant. Both latent variables made their effects felt through Experience, which in turn had a direct and significant effect on Learning. Overall, therefore, it can be stated that a simulation game that is challenging and exciting, and thereby also offers an experience to students, will have a positive impact with respect to their perceived learning. At the same time, challenging tasks or mere exciting exercises alone will not achieve a significant impact if the experience factor is missing from the characteristics of the simulation game, since it is this which has the greatest beneficial effect on learning, and through which all other typical effects are mediated or filtered.

\section{LIMITATIONS OF THE METHODOLOGY AND FURTHER DIRECTIONS OF RESEARCH}

Naturally, there are certain limitations to the interpretation of the results of the empirical research presented here. The research of Hamari et al. (2016) provided the framework for the collection of data through a questionnaire; the survey which they validated already represented a tried and tested basis, even if the grouping of questions in sequence might potentially have influenced the respondents. In addition, it should be noted that the employed Likert scale lies - in the judgement of experts - at the junction between an ordinal and an interval scale, which likewise needs to be taken into account in light of our choice of methodology. With regard to the sample size, the number of participants in the research exceeds the threshold value of 100 , and is similar to other examinations of similar research questions (Hamari et al., 2016: $\mathrm{n}=174$; Ranchhod et al., 2014: $\mathrm{n}=305$; Geithner and Menzel, 2016: $n=47$ ), while also conforming to the minimum requirements of the chosen methodologies.

Potential exists for the advancement of the methodology at a number of points. The evaluation model could probably be improved by refining the questionnaire and increasing the number of those questioned. It would be worthwhile examin- 
ing various age groups and students according to their different specialised areas of study, while it might also prove useful to employ a control group, something the present research did not allow. While our research measured perceived learning based on the assessment of students, the measurement of learning efficiency could be elevated to an objective level with the aid of various tests. Besides all this - as we suggested earlier - a cultural projection of the research might also prove interesting. Our comparison of the two surveys has already revealed that for American students Challenge contributed more to Learning than Engagement/Experience. Further international comparative studies, or a collection of data extending to the cultural characteristics of students, might also yield additional interesting results. 


\section{REFERENCES}

BEHJAT, F. - YAMINI, M. - BAgheRI, M. (2012): Blended learning: A ubiquitous learning environment for reading comprehension. International Journal of English Linguistics, 2(1), 97-104. https://doi. org/10.5539/ijel.v2nıp97.

Bonk, C. J. - Graham, C. R. (2006): Handbook of blended learning: Global perspectives, local designs. San Francisco, CA: Pfeiffer Publishing.

Cerny, C. A. - Kaiser, H. F. (1977): A study of a measure of sampling adequacy for factor-analytic correlation matrices. Multivariate Behavioral Research 12(1), 43-47.

ChIN, W. W. (1998): The partial least squares approach to sructural equation modeling. Chapter 10. In: Marcoulides, G. A. (1998): Modern methods for business research. London: Lawrence Erlbaum Associates, 295-336.

CsAPó, B. (2002): A tudáskoncepció változása: nemzetközi tendenciák és a hazai helyzet [Changes in the concept of knowledge: international trends and the situation in Hungary]. Uj Pedagógiai Szemle 52(2), 38-45.

Deterding, S. - Dixon, D. - Khaled, R. - Nacke, L. (2011): From Game Design Elements to Gamefulness - Defining „Gamification”. MindTrek ,11 Proceedings of the 15th International Academic MindTrek Conference: Envisioning Future Media Environments, 9-15. https://doi. org/10.1145/2181037.2181040.

DocsA, G. - SZlÁviK, P. (2015.10.13-14.): Opportunities in blended learning - how can simulations boost training programs? 10th IWKM 2015, Pozsony, Szlovákia.

ForGó, S. (2009): Az új média és az elektronikus tanulás [New media and electronic learning]. Új Pedagógiai Szemle 59(9), 91-96.

GARRISON, D. R. - KANUKA, H. (2004): Blended learning: Uncovering its transformative potential in higher education. The Internet and Higher Education 7(2), 95-105. https://doi.org/10.1016/j. iheduc.2004.02.001.

Geithner, S. - Menzel, D. (2016): Effectiveness of learning through experience and reflection in a project management simulation. Simulation \& Gaming 47(2), 228-256. https://doi. org/10.1177/1046878115624312.

Greer, D. - Rowland, A. - Smith, S. (2014): Critical considerations for teaching students with disabilities in online environments. Teaching Exceptional Children 46(5), 79-91. https://doi. org/10.1177/0040059914528105.

Hair, J. F. Jr. - Hult, G. T. M. - Ringle, C. M. - Sarstedt, M. (2017): A Primer on Partial Least Squares Structural Equation Modeling (PLS-SEM). Los Angeles, USA: SAGE Publications, Inc.

Hamari, J. - Shernoff, D. J. - Rowe, E. - Coller, B. - Asbell-Clarke, J. - Edwards, T. (2016): Challenging games help students learn: An empirical study on engagement, flow and immersion in game-based learning. Computers in Human Behavior 54, 170-179. https://doi.org/10.1016/j. chb.2015.07.045

JózsA, K. (2000): Az elsajátítási motiváció szerepe a kritériumorientált pedagógiában [The role of the mastery motivation in criterion-oriented pedagogy]. Új Pedagógiai Szemle 50(10), 78-82.

KolB, D. A. (1984): Experiential learning. Englewood Cliffs, NJ: Prentice Hall.

Kovács, E. (2011): Pénzügyi adatok statisztikai elemzése [Statistical Analysis of Financial Data]. Corvinus University of Budapest, Institute of Finance and Accounting, Budapest:Tanszék Kft.

Krishnan, S. (2016): Students' perceptions of learning mode in mathematics. The Malaysian Online Journal of Educational Sciences 4(2), 32-41.

Lalima, K. - Dangwal, L. (2017): Blended Learning: An Innovative Approach. Universal Journal of Educational Research 5(1), 129-136. https://doi.org/10.13189/ujer.2017.050116. 
Matute, J. - Melero, I. (2016): Game-based learning: using business simulators in the university classroom/Aprender jugando: la utilización de simuladores empresariales en el aula universitaria. Universia Business Review 51, 72.

Merkovity, N. - NemesLaki, A. (2014): eLearning fejlesztések a közszolgálatokban: Szerkesztői előszó [eLearning Developments in Public Services: Editors' Foreword]. Információs Társada$\operatorname{lom} 14(1), 5-8$.

Motorola University (1996): Creating Mindware for the $21^{\text {st }}$ Century. Corporate University Xchange 2(3), and Alexandria: NTL Institute for Applied Behavioral Science.

Osguthorpe, R. T. - Graham, C. R. (2003): Blended Learning Systems: Definitionas and directions In: Bonk, C. J. - Graham, C. R (2006): Handbook of blended learning: Global perspectives, local designs. San Francisco, CA: Pfeiffer Publishing.

PÁszTor, A. (2014): Lehetőségek és kihívások a digitális játék alapú tanulásban: egy induktív gondolkodást fejlesztő program hatásvizsgálata [Opportunities and Challenges in Digital GameBased Learning: A Study of the Impact of a Program Developing Inductive Reasoning]. Magyar Pedagógia 114(4), 281-302.

Prensky, M. (2001): Digital Natives, Digital Immigrants. On the Horizon, MCB University Press 9(5). https://doi.org/10.1108/10748120110424816.

RanchHod, A. - GuRăU, C. - Loukis, E. - Trivedi, R. (2014): Evaluating the educational effectiveness of simulation games: A value generation model. Information Sciences 264, 75-90. https:// doi.org/10.1016/j.ins.2013.09.008.

Rogers, C. R. (1969): Freedom to learn. Columbus, OH: Charles E. Merrill.

Sauvé, L. - Renaud, L. - Kaufman, D. - Marquis, J. S. (2007): Distinguishing between games and simulations: A systematic review. Educational Technology \& Society 10(3), 247-256.

SNedecor, G. W. - Cochran, W. G. (1989): Statistical Methods, $8^{\text {th }}$ Edition. Iowa: Iowa State University Press.

TaO, Y. H. - Cheng, C. J. - Sun, S. Y. (2009): What influences college students to continue using business simulation games? The Taiwan experience. Computers \& Education 53(3), 929-939. https://doi.org/10.1016/j.compedu.2009.05.009. 